\title{
A Study on Changes in the Facial Soft and Hard Tissues Associated with the Treatment of Anterior Crossbite -With Reference to the Application of Moiré Topography-
}

\author{
by \\ Sayoko MASUTANI
}

\section{Introduction}

In recent years, a new measuring technique using moiré topography has been introduced into the field of dentistry and various measurements have since been made of the face, the palate, the alveolar ridge and the like. This particular technique is advantageous over other measuring techniques, including contour cartography, in that it is simple to manipulate, it makes measurement possible without touching variable portions and it also permits qualitative as well as quantitative analysis. Especially in the field of orthodontics, studies have been made on the facial characteristics of malocclusal patients and of the facial changes before and after treatment.

Studies on facial soft tissue have hitherto been conducted mainly in two dimensions using lateral cephalometric radiographs and facial photographs.

In this study the author employed moiré topography and, from a standpoint of quantitative analysis, made observations of the morphological changes in the facial soft tissties of anterior crossbite patients after bite improvement by means of an FKO apparatus. The author also studied how the sectional areas were interrelated. Another purpose of this study was to learn about the relationships between the morphological changes in the soft tissue in the upper lip region and the changes in measurement values obtained from lateral cephalometric radiographs.

\section{Materials and Methods}

1. Materials

Of the anterior crossbite patients treated in the Department of Orthodontics, Nihon University Dental Hospital, a selective use was made of 39 patients (17 males and 22 females) whose bites had been improved using an FKO apparatus. In this study the frontal moiré photographs and the lateral cephalometric radiographs before and after treatment were used.

The mean age of the above-mentioned 39 subjects when treatment started was 9 years and 5 months. Fifteen belonged to III A, 21 to III B and 3 to III C according to Helman's classification of dental ages. The treatment periods ranged from 39 to 209 days. The mean period was 92 days. The crossbite conditions and the presence of maxillary cuspids were studied using Angle's models.

利谷佐代子: Department of Clinical Dentistry, Nihon University Graduate School of Dentistry (Director: Prof. Masatoshi ARITA). 
2. Methods

In moiré photography the author followed KAMONJI's method. After the point of the left-eye socket was marked on each subject, he was instructed to repeat articulation at centric occlusion without constricting the lips. Right and left earrods were then inserted in the auricular orifices. The eye-point indicator, designed to be horizontal to the floor, was placed in position as so to be in agreement with the point of the left-eye socket to prevent horizontal as well as vertical movements. Frontal photographs were then taken.

The photographic apparatus was a Fujinon Moiré Camera FM-3011, a product of the Fuji Film Company. The intervals between the isobars were set at $2 \mathrm{~mm}$, the shutter speed at $1 / 8 \mathrm{sec}$. and the lens opening at F8 or F16.

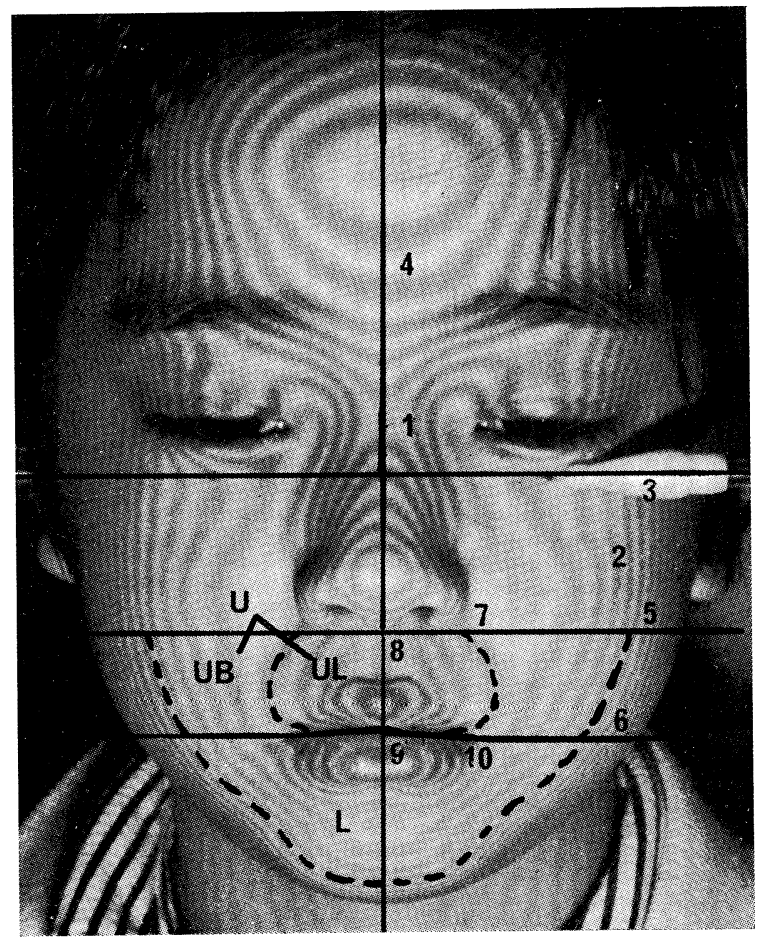
1. $S p n$
8. $S n$
2. Basic moiré contours
9. Sto
3. FHP
10. $\mathrm{Ch}$
4. Median line
UL Upper lip region
5. $\mathrm{SnP}$
UB Buccal region
6. StoP
U Upper jaw
7. Outermost part of
L Lower jaw upper lip

Fig. 1 Landmarks for moiré photography 
The exposed film was developed and positive pictures (Fujifilm WP-4) half as large as life were prepared. Frontal moiré photographs were thus obtained.

The measurement landmarks (the base points, the base planes and the base moiré stripes) are shown in Fig. 1.

The base points

Spn: The lowest point of the root of the nose; the median point between the inner canthi of both eyes

Sn: The apex of the angle formed by the lower edge of the membranous part of the nasal septum and the dermal surface of the upper lip

Sto: The point of junction of the oral fissure and the median line with the mouth lightly closed

Ch: The points in the angles of the mouth where the vermilion labial margins meet at both lateral ends

The base planes

FHP: The line that passes the center of the indicator designed to indicate the point of the left-eye socket

Facial median line: The line that vertically crosses FHP through Spn

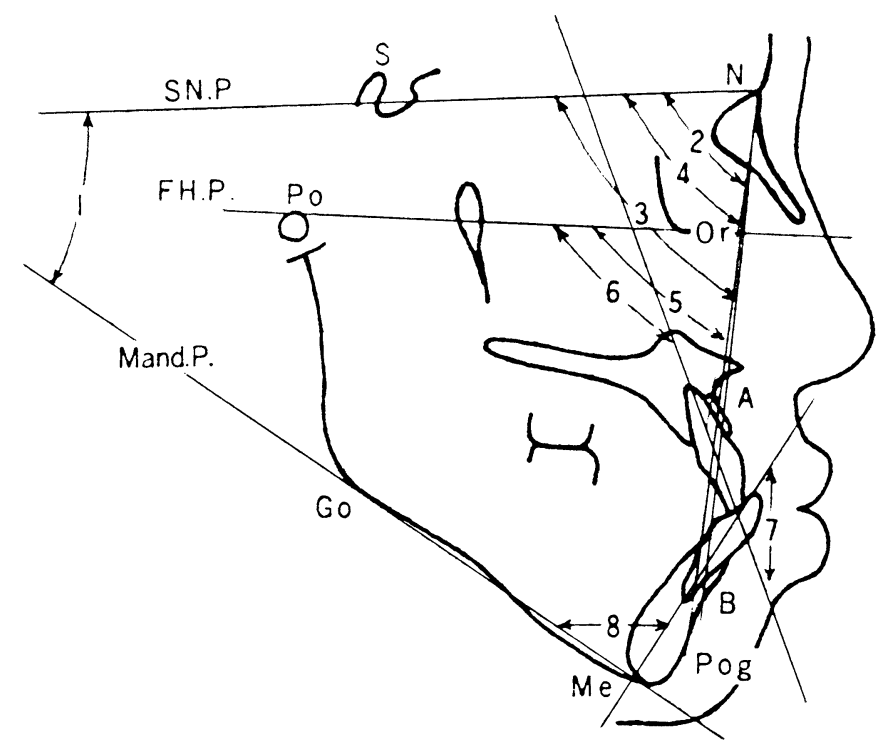

1. $S N$ to mand.

5. Facial angle

2. SNA

6. $\mathrm{FH}$ to 1

3. $S N B$

7. 1 to $T$

4. SN-Pog.

8. Mand to $T$

Fig. 2 Measurement landmarks for angles 


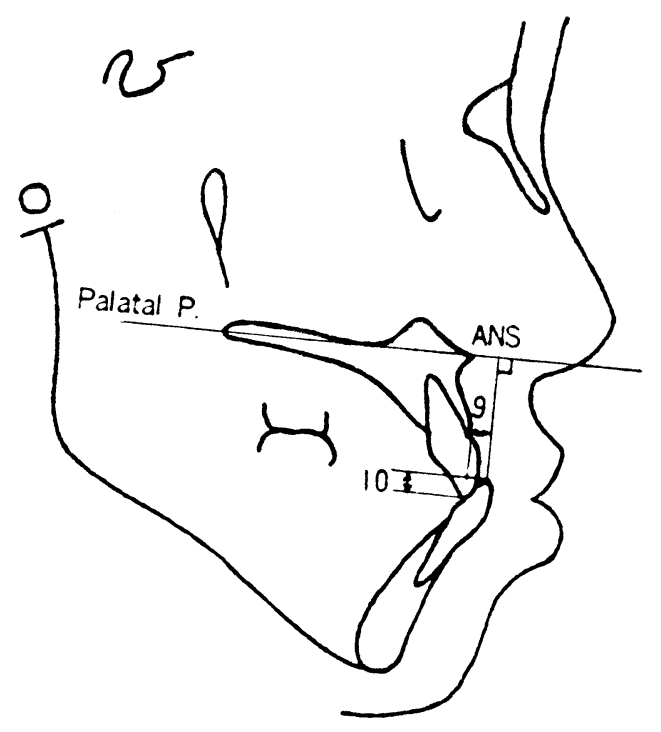

9. Over jet

10. Over bite

Fig. 3 Measurement landmarks for distance items

The base moiré contours

In accordance with KAMONJI's method, the fifteenth line (counting both black and white contours) going downward externally from Spn was used as the base.

The method for measuring frontal moiré photographs

As shown in Fig. 1, a line that passes Sn and runs parallel to FHP was drawn and designated as SnP. The line that links $\mathrm{Ch}$, Sto and $\mathrm{Ch}^{\prime}$ was further extended outward from $\mathrm{Ch}$ and $\mathrm{Ch}^{\prime}$, parallel to FHP, and was designated as StoP. The upper jaw (U) is a section formed by $\mathrm{SnP}$, the base moiré contour and StoP. The lower jaw (L) is a section formed by StoP and the base moiré contour. The upper jaw was divided into two sections: the upper lip region (UL), an area sorrounded by the outermost contours extending from the wings of the nose to the oral fissure and the upper buccal region (UB), an area extending outward from the next contour to the base moiré contour.

Measurements were made of the surface area and volume of each section using a summagraphic apparatus (FORM 16, manufactured by Summagraphics).

Measurement of the upper lip region

The width, height and depth of the upper lip region were measured. The width was the maximum width of the upper lip region and the height was the distance from $\mathrm{Sn}$ on the facial median line to Sto. $1 / 20 \mathrm{~mm}$ vernier calipers were used for measurement. As for the depth, the mean number of contours from the outermost 
Table 1 Samples in the present study

\begin{tabular}{|c|c|c|c|c|c|c|c|c|c|}
\hline case & sex & age & $\begin{array}{c}\text { dental age } \\
\text { Helman }\end{array}$ & $\begin{array}{c}\text { treatment } \\
\text { period (days) }\end{array}$ & case & sex & age & $\begin{array}{c}\text { dental age } \\
\text { Helman }\end{array}$ & $\begin{array}{c}\text { treatment } \\
\text { period (days) }\end{array}$ \\
\hline 1 & $\mathrm{~F}$. & $7 \mathrm{y} \cdot 7 \mathrm{~m}$ & III $\Lambda$ & 43 & 21 & $M$ & $9 \mathrm{y} \cdot 4 \mathrm{~m}$. & ШII B & 74 \\
\hline 2 & $M$ & $7 y \cdot 8 m$ & III $B$ & 90 & 22 & F. & $9 y \cdot 5 \mathrm{~m}$. & III A & 76 \\
\hline 3 & M. & $7 \mathrm{y} .9 \mathrm{~m}$ & IIIA & 92 & 23 & $\mathrm{~F}$. & $9 y \cdot 6 m$. & IIIB & 98 \\
\hline 4 & $\mathrm{~F}$. & $7 \mathrm{y} \cdot 10 \mathrm{~m}$ & IIIA & 42 & 24 & $\mathrm{~F}$ & $9 \mathrm{y} .6 \mathrm{~m}$. & III $B$ & 85 \\
\hline 5 & M. & $7 \mathrm{y} \cdot 10 \mathrm{~m}$ & IIIA & 78 & 25 & F. & $9 \mathrm{y} \cdot 6 \mathrm{~m}$. & III B & 122 \\
\hline 6 & M. & $7 \mathrm{y} .11 \mathrm{~m}$. & III B & 147 & 26 & M. & $9 y \cdot 9 m$. & IIIA & 95 \\
\hline 7 & F. & $7 \mathrm{y} .11 \mathrm{~m}$. & III B & 209 & 27 & M. & $10 \mathrm{y} .0 \mathrm{~m}$. & III B & 39 \\
\hline 8 & F. & $8 \mathrm{y} .0 \mathrm{~m}$ & III B & 114 & 28 & M. & $10 \mathrm{y} \cdot 2 \mathrm{~m}$. & III B & 197 \\
\hline 9 & M. & $8 \mathrm{y} \cdot 2 \mathrm{~m}$. & III A & 58 & 29 & F. & $10 \mathrm{y} \cdot 2 \mathrm{~m}$ & III B & 120 \\
\hline 10 & M. & $8 \mathrm{y} \cdot 2 \mathrm{~m}$. & IIIA & 75 & 30 & $\mathrm{M}$ & $10 \mathrm{y} \cdot 7 \mathrm{~m}$. & III $B$ & 71 \\
\hline 11 & $\mathrm{~F}$. & $8 \mathrm{y} \cdot 3 \mathrm{~m}$. & IIIA & 57 & 31 & $F$. & $10 \mathrm{y} .8 \mathrm{~m}$ & III B & 54 \\
\hline 12 & F. & $8 \mathrm{y} \cdot 4 \mathrm{~m}$. & III B & 52 & 32 & $\mathrm{~F}$. & $10 \mathrm{y} .8 \mathrm{~m}$. & III $B$ & 42 \\
\hline 13 & M. & $8 \mathrm{y} \cdot 5 \mathrm{~m}$. & IIIIA & 76 & 33 & $\mathrm{~F}$. & $10 \mathrm{y} \cdot 8 \mathrm{~m}$ & III B & 77 \\
\hline 14 & $\mathrm{~F}$. & $8 \mathrm{y} \cdot 6 \mathrm{~m}$. & IIIA & 61 & 34 & F. & $10 \mathrm{y} \cdot 9 \mathrm{~m}$ & III B & 53 \\
\hline 15 & M. & $8 y \cdot 9 m$. & III A & 156 & 35 & $M$. & $10 \mathrm{y} \cdot 10 \mathrm{~m}$ & III B & 45 \\
\hline 16 & F. & $8 \mathrm{y} \cdot 10 \mathrm{~m}$. & III B & 149 & 36 & M. & $10 \mathrm{y} .11 \mathrm{~m}$. & III $A$ & 42 \\
\hline 17 & $\mathrm{~F}$. & $8 \mathrm{y} \cdot 11 \mathrm{~m}$ & IIIA & 132 & 37 & $\mathrm{M}$ & $11 \mathrm{y} \cdot 2 \mathrm{~m} \cdot$ & mi $c$ & 104 \\
\hline 18 & $\mathrm{~F}$ & $8 \mathrm{y} \cdot 11 \mathrm{~m}$. & III B & 126 & 38 & $\mathrm{~F}$. & $11 \mathrm{y} \cdot 5 \mathrm{~m}$. & III C & 121 \\
\hline 19 & M. & $9 y .3 \mathrm{~m}$. & III B & 141 & 39 & $\mathrm{~F}$. & $12 \mathrm{y} \cdot 7 \mathrm{~m}$ & IIIC & 134 \\
\hline 20 & $\mathrm{~F}$. & $9 \mathrm{y} .3 \mathrm{~m}$. & III A & 58 & mean & & $9 \mathrm{y} \cdot 5 \mathrm{~m}$. & & 92 \\
\hline
\end{tabular}

moiré contour to the highest moiré contour in the upper lip region, on both the left and right sides, was evaluated.

Analysis of the lateral cephalometric radiographs

IIZUKA ET AL.'s method was used for measuring the lateral cephalometric radiographs. For angle measurements 8 items (Fig. 2), expected to show changes resulting from the use of the FKO technique, and 2 items (Fig. 3) for measuring distances were selected from the series of criteria of both Down's and Northwestern's analysis.

\section{Results}

1. The rates of change in the surface area and volume of each section before and after the improvement of bite observed on the frontal moiré photographs are shown in Table 1. In computing the rates of change the formula:

$$
\frac{\text { post-op. }- \text { pre-op. }}{\text { pre-op. } \times 100(\%)}
$$


Table 2 Change in the surface of each region

\begin{tabular}{|c|cccc|c|ccccc|}
\hline case & UL. & UB & U & L & Case & UL & UB & U & L \\
\hline 1 & +6.36 & +5.07 & +5.62 & -10.56 & 21 & +17.11 & -2.36 & +5.80 & +11.10 \\
2 & -3.45 & -2.42 & -2.81 & -21.97 & 22 & +2.03 & +7.83 & +5.66 & -20.12 \\
3 & -9.03 & -2.1 .93 & -18.69 & +0.67 & 23 & +1.66 & +5.65 & +4.36 & -11.12 \\
4 & +11.95 & -9.05 & -1.51 & -0.94 & 24 & +17.98 & -24.34 & -10.77 & -56.86 \\
5 & +3.19 & -14.26 & -5.64 & -21.18 & 25 & +6.57 & -6.28 & -0.41 & +0.12 \\
6 & -0.97 & +9.57 & +4.33 & +2.73 & 26 & +20.39 & -1.33 & +8.15 & -15.90 \\
7 & -0.72 & +23.68 & +13.42 & -5.72 & 27 & -10.32 & +4.31 & -2.43 & -28.07 \\
8 & -25.97 & -3.29 & -13.64 & -24.75 & 23 & +4.15 & -0.95 & +0.99 & -18.36 \\
9 & -0.92 & -8.87 & -5.37 & -33.46 & 29 & -1.17 & -26.05 & -16.86 & -11.27 \\
10 & -1.24 & -6.81 & -4.61 & -8.08 & 30 & +2.77 & -1.02 & +0.71 & -4.54 \\
1.1 & +3.49 & -1.99 & -0.06 & +1.42 & 31 & -2.72 & -5.98 & -5.49 & -5.29 \\
12 & +14.89 & -13.92 & -3.45 & -1.50 & 32 & -2.55 & -14.07 & -8.05 & -5.74 \\
13 & +2.83 & +12.27 & +7.75 & -22.48 & 33 & -9.23 & +12.53 & +1.35 & -3.12 \\
14 & -4.05 & -4.31 & -4.19 & -11.70 & 34 & +0.89 & +3.18 & +2.41 & -0.44 \\
15 & +1.19 & +9.51 & +5.49 & -7.13 & 35 & -6.43 & +5.92 & +1.04 & -4.96 \\
16 & -3.87 & -12.90 & -9.77 & -24.01 & 36 & +1.1 .55 & -6.03 & +0.92 & -28.99 \\
17 & -5.33 & -10.66 & -8.56 & -21.86 & 37 & +2.49 & -19.28 & -8.71 & -30.96 \\
18 & +9.09 & +5.26 & +6.98 & +14.29 & 38 & +8.83 & -6.31 & -0.81 & -7.33 \\
19 & -2.27 & +2.65 & +0.43 & -29.40 & 39 & -18.58 & +14.01 & -2.54 & -31.77 \\
20 & +1.22 & -0.25 & +4.22 & -15.80 & mean & +1.46 & -2.69 & -1.39 & -13.21 \\
\hline
\end{tabular}

was used. In the tabulation, the positive sign $(+)$ indicates an increase and the negative sign $(-)$ means a decrease after treatment.

The rates of change in the surface area and volume are shown in Tables 2 and 3.

Table 4 shows the mean values and differences in the width, height and depth of the upper lip region before and after treatment.

2. The analytical values of the lateral cephalometric radiographs and the mean values of their differences before and after treatment are shown in Table 5.

3. The models of the oral cavity showed that there were 24 cases of anterior crossbite involving deciduous or permanent cuspids on both sides of the mandible $(61.5 \%)$ and 28 cases with deciduous or permanent cuspids on both sides of the maxilla $(71.8 \%)$.

4. Table 6 shows the measurement values for the 6 items believed to be mainly responsible for changes in the hard tissues as observed on the lateral cephalometric radiographs. It also shows the rates of change in the surface area and volume of the soft tissue of each section as well as correlations between the width, height and depth. A single asterisk * shows the correlation at a significant level of $5 \%$ and a double asterisk $* *$, the correlation at a significant level of $1 \%$. 
Table 3 Change in the volume of each region

\begin{tabular}{|c|cccc||c|c|cccc|}
\hline case & UL & UB & U & L & Case & UL & UB & U & L \\
\hline 1 & +1.96 & -1.83 & +0.50 & -24.15 & 21 & +29.60 & +1.37 & +18.75 & +20.91 \\
2 & -6.20 & -12.74 & -9.09 & -32.50 & 22 & -0.46 & +4.93 & +2.01 & -35.09 \\
3 & -0.99 & -20.20 & -13.15 & -10.80 & 23 & -4.48 & +0.77 & -1.69 & -27.80 \\
4 & +15.93 & -11.05 & +2.78 & +2.77 & 24 & +0.45 & -54.83 & -26.63 & -64.30 \\
5 & -3.10 & -28.02 & -13.48 & -43.04 & 25 & +15.50 & -2.36 & +9.44 & +1.57 \\
6 & +7.51 & +27.62 & +13.37 & -12.75 & 26 & +24.88 & +1.16 & +16.21 & -23.11 \\
7 & -4.48 & +28.17 & +8.44 & -31.21 & 27 & -21.14 & -3.24 & -15.07 & -45.81 \\
8 & +4.19 & -16.16 & -1.82 & -35.12 & 28 & -4.08 & -12.07 & -7.61 & -41.01 \\
9 & -4.70 & -21.05 & -10.59 & -42.84 & 29 & -2.83 & -24.37 & -11.81 & -17.92 \\
10 & -2.38 & -12.12 & -6.64 & -21.93 & 30 & -1.82 & -1.93 & -1.86 & -25.53 \\
11 & +2.53 & -7.44 & -2.37 & -8.25 & 31 & -5.70 & -9.91 & -7.78 & -19.23 \\
12 & +15.15 & -20.76 & -1.44 & -8.50 & 32 & -4.01 & -16.28 & -7.07 & -13.84 \\
13 & -4.29 & +7.64 & -0.58 & -40.05 & 33 & -8.41 & +10.81 & -2.46 & -19.31 \\
14 & -6.43 & -8.40 & -7.11 & -17.53 & 34 & -1.43 & +2.44 & +1.96 & -8.36 \\
15 & +5.34 & +15.57 & +8.41 & -12.18 & 35 & -8.89 & +5.50 & -2.57 & -18.20 \\
16 & -12.86 & -23.30 & -18.12 & -47.59 & 36 & +8.16 & -18.63 & -4.06 & -42.14 \\
17 & -17.49 & -23.64 & -20.04 & -38.04 & 37 & -3.07 & -34.44 & -12.60 & -41.61 \\
18 & +21.80 & +15.80 & +19.74 & +26.16 & 38 & +1.77 & -14.22 & -5.74 & -23.04 \\
19 & -2.97 & +1.10 & -1.58 & -40.13 & 39 & -22.44 & +11.35 & -12.68 & -49.12 \\
\cline { 6 - 8 } 20 & +1.07 & -8.47 & -3.07 & -29.41 & mean & +0.03 & -7.01 & -3.26 & -24.62 \\
\hline & & & & & & & & & $(\%)$ \\
\hline
\end{tabular}

Table 4 Means of width, height and depth in upper lip region

\begin{tabular}{|c|c|c|c|}
\hline & $\begin{array}{c}\text { Width } \\
(\mathrm{mm})\end{array}$ & $\begin{array}{c}\text { Height } \\
(\mathrm{mm})\end{array}$ & $\begin{array}{c}\text { Depth } \\
(\mathrm{mm})\end{array}$ \\
\hline Before & $\begin{array}{c}43.9 \\
(5.7)\end{array}$ & $\begin{array}{c}18.7 \\
(2.0)\end{array}$ & $\begin{array}{c}9.4 \\
(1.5)\end{array}$ \\
\hline After & $\begin{array}{l}42.0 \\
(4.8)\end{array}$ & $\begin{array}{l}19.2 \\
(2.0)\end{array}$ & $\begin{array}{c}9.8 \\
(1.3)\end{array}$ \\
\hline Deff. & -1.9 & +0.5 & +0.4 \\
\hline
\end{tabular}


Table 5 Means of radio cephalometric analysis before and after treatment

\begin{tabular}{|c|c|c|c|c|c|c|c|c|c|c|}
\hline ment & $\begin{array}{l}S N \text { to } \\
\text { Mand. }\end{array}$ & SNA & SNB & SNPOg & \begin{tabular}{|c|} 
Facial \\
Angle \\
\end{tabular} & FHto 1 & 1 to $\bar{T}$ & $\begin{array}{l}\text { Mand. } \\
\text { to } \frac{1}{1}\end{array}$ & $\begin{array}{c}\text { over jet } \\
(\mathrm{mm})\end{array}$ & $\begin{array}{c}\text { over bite } \\
(\mathrm{mm})\end{array}$ \\
\hline Before & 36.8 & 79.0 & 79.1 & 78.7 & 85.9 & 107.0 & 134.7 & 88.6 & -3.6 & 4.1 \\
\hline After & 38.8 & 79.0 & 77.6 & 77.2 & 84.1 & 113.8 & 129.2 & 84.8 & 2.0 & 1.5 \\
\hline Diff. & +2.0 & 0.0 & $-1.5^{*}$ & $-1.5^{*}$ & $-1.8^{*}$ & $+6.8 * *$ & $-5.4^{* *}$ & $-3.8^{*}$ & $+5.6^{* *}$ & $-2.5^{* *}$ \\
\hline
\end{tabular}

Table 6 Correlation coefficient value between hard tissue and soft tissue

\begin{tabular}{|c|c|c|c|c|c|c|c|c|c|c|c|}
\hline & \multicolumn{4}{|c|}{$S$ group } & \multicolumn{4}{|c|}{$\mathrm{V}$ group } & \multicolumn{3}{|c|}{ UL } \\
\hline & UL & $\mathrm{UB}$ & $\mathrm{U}$ & L & UL & UB & $\mathrm{U}$ & L & Width & Height & Depth \\
\hline $\mathrm{SN}$ to mand & -0.089 & 0.143 & 0.100 & 0.017 & -0.130 & 0.130 & 0.023 & -0.187 & $-0.347^{\star}$ & 0.290 & -0.261 \\
\hline FH to $\underline{1}$ & 0.164 & -0.154 & -0.033 & 0.071 & 0.229 & -0.088 & 0.104 & 0.102 & 0.054 & 0.101 & -0.056 \\
\hline $\begin{array}{c}\text { mand to } 1 \\
-\end{array}$ & -0.098 & 0.136 & 0.031 & -0.099 & -0.144 & 0.049 & -0.099 & -0.164 & -0.279 & 0.063 & -0.140 \\
\hline \multirow{2}{*}{$\begin{array}{l}\underline{1} \text { to } \bar{l} \\
\text { over jet }\end{array}$} & 0.001 & 0.013 & 0.004 & 0.108 & -0.050 & 0.065 & 0.002 & 0.160 & 0.190 & -0.237 & 0.073 \\
\hline & -0.120 & 0.253 & 0.177 & 0.038 & -0.157 & 0.276 & 0.087 & -0.076 & -0.293 & 0.067 & -0.129 \\
\hline over bite & -0.001 & -0.297 & -0.261 & 0.032 & 0.028 & -0.286 & -0.171 & 0.156 & 0.280 & -0.254 & 0.081 \\
\hline UL & & -0.214 & $0.376^{*}$ & 0.127 & $0.678 * *$ & -0.165 & $0.324^{\star}$ & 0.252 & $0.564^{* *}$ & 0.168 & $0.439 * *$ \\
\hline 今. UB & & & $0.814 * \star$ & 0.222 & -0.087 & $0.901^{\star \star}$ & $0.537^{\star \star}$ & 0.075 & $-0.443^{\star *}$ & 0.241 & -0.266 \\
\hline $\begin{array}{l}\text { है U } \\
\text { ज }\end{array}$ & & & & 0.314 & & & $0.723^{\star \star}$ & 0.244 & -0.069 & $0.318^{\star}$ & 0.016 \\
\hline L & & & & & $0.478^{\star *}$ & $0.528^{\star \star}$ & $0.674^{* *}$ & $0.917^{\star \star \star}$ & 0.309 & -0.282 & 0.175 \\
\hline \multirow{4}{*}{$\begin{array}{ll}\text { 口े } & \text { UB } \\
\text { हैं } & \\
\text { bे } & \mathrm{U} \\
\dot{-} & \mathrm{L}\end{array}$} & & & & & & 0.116 & $0.741^{\star \star}$ & $0.665 \star \star$ & $0,689 * \star$ & -0.029 & 0.454 ** \\
\hline & & & & & & & $0.734 * \star$ & $0.396^{\star}$ & -0.280 & 0.077 & -0.180 \\
\hline & & & & & & & & $0.713^{\star \star}$ & 0.297 & 0.028 & 0.198 \\
\hline & & & & & & & & & $0.482^{\star \star}$ & -0.295 & 0.278 \\
\hline
\end{tabular}

* : Significant at: $5 \%$ level

** : Significant at $1 \%$ level.

\section{Discussion}

Based on the analytical values of the lateral cephalometric radiographs, the healing process for anterior crossbite patients, using an FKO apparatus, went through a rotation of the mandibular body, a lingual inclination of the mandibular anteriors and a labial inclination of the maxillary anteriors. This was in agreement with previous reports.

Relationships between the hard and soft tissues deserve no special mention. It is believed that changes brought about in the hard tissue using an FKO apparatus do not directly affect the surface area and volume of the soft tissue.

In the region of the soft tissue, changes in the UL are considered significant. 
Table 7 Changes in upper lip region (surface)

\begin{tabular}{|c|c|c|c|c||c|c|c|}
\hline \multirow{2}{*}{ measurement } & \multicolumn{3}{|c||}{ Hard tissue } & \multicolumn{3}{|c|}{ Soft tissue } \\
\cline { 2 - 7 } & $\begin{array}{c}\text { gN to } \\
\text { mand. }\end{array}$ & FHto 1 & $\begin{array}{c}\text { Mand. } \\
\text { to } \frac{1}{1}\end{array}$ & $\begin{array}{c}\text { Width } \\
(\mathrm{mm})\end{array}$ & $\begin{array}{c}\text { Height } \\
(\mathrm{mm})\end{array}$ & $\begin{array}{c}\text { Depth } \\
(\mathrm{mm})\end{array}$ \\
\hline $\mathrm{S}(+)$ & 12 & +1.4 & +7.7 & -3.9 & +1.6 & +0.5 & +1.1 \\
\hline $\mathrm{S}( \pm)$ & 20 & +2.4 & +6.6 & -4.0 & -3.0 & +0.4 & +0.2 \\
\hline$S(-)$ & 7 & +2.1 & +6.1 & -3.2 & -5.0 & +0.4 & 0 \\
\hline
\end{tabular}

unit : degree

Table 8 Changes in upper lip region (volume)

\begin{tabular}{|c|c|c|c|c||c|c|c|}
\hline \multicolumn{2}{|c|}{$\begin{array}{c}\text { measure } \\
\text { ment }\end{array}$} & \multicolumn{3}{c||}{ Hard tissue } & \multicolumn{3}{c|}{ Soft tissue } \\
\cline { 2 - 8 } group case & $\begin{array}{c}\text { SN to } \\
\text { Mand. }\end{array}$ & FHto 1 & $\begin{array}{c}\text { Mand. } \\
\text { to } \frac{1}{1}\end{array}$ & $\begin{array}{c}\text { Width } \\
(\mathrm{mm})\end{array}$ & $\begin{array}{c}\text { Height } \\
(\mathrm{mm})\end{array}$ & $\begin{array}{c}\text { Depth } \\
(\mathrm{mm})\end{array}$ \\
\hline$V(t)$ & 9 & +1.5 & +7.3 & -4.2 & +1.2 & +0.9 & +1.0 \\
\hline$V( \pm)$ & 21 & +2.4 & +7.5 & -3.7 & -1.9 & +0.6 & +0.2 \\
\hline$V(-)$ & 9 & +1.6 & +5.4 & -3.4 & -4.2 & +0.2 & +0.1 \\
\hline
\end{tabular}

unit : degree

They occur irrespective of changes that take place in the hard tissue of the UB. Thus, the author was led to believe that conditions of the mandibular and maxillary anteriors are responsible for changes in the UL. The rate of presence of the deciduous or permanent cuspids on both sides of the maxilla and the rate of anterior crossbite involving deciduous or permanent cuspids on both sides of the mandible were studied. Changes in the surface area and volume of the UL were also examined (Tables 7, 8, 9 and 10).

It is considered that the higher the rate of presence of the deciduous or permanent cuspids on both sides of the maxilla, the greater the recovery of fullness in the UL due to maxillary deciduous or permanent cuspids. Also, the higher the rate of anterior crossbite involving deciduous or permanent cuspids on both sides of the mandible, the greater is the upward push of the upper lip. After treatment much of this upward push will disappear. 
Table 9

\begin{tabular}{|c|c|c|c|}
\hline & Case & $\frac{\mathrm{ClC} \text { or } 3 / 3}{\text { Existence }}$ & $\begin{array}{l}\overline{C+C} \text { or } \overline{3+3} \\
\text { Cross bite }\end{array}$ \\
\hline$S(t)$ & 12 & $\begin{array}{c}8 \\
(66.7)\end{array}$ & $\begin{array}{c}6 \\
(50.0)\end{array}$ \\
\hline$S( \pm)$ & 20 & $\begin{array}{c}16 \\
(80.0)\end{array}$ & $\begin{array}{c}14 \\
(65.0)\end{array}$ \\
\hline$S(-)$ & 7 & $\begin{array}{c}4 \\
(57.1)\end{array}$ & $\begin{array}{c}5 \\
(71.4)\end{array}$ \\
\hline
\end{tabular}

Table 10

$\mathrm{ClC}$ or $3 \mid 3$ existence and $\overline{C F C}$ or $\bar{अ} 3$ cross bite in each of $v$ group

\begin{tabular}{|c|c|c|c|}
\hline & Case & $\frac{C \mid C \text { or } 3 / 3}{\text { Existence }}$ & $\begin{array}{c}\overline{C F} \text {. or 3+3 } \\
\text { Cross bite }\end{array}$ \\
\hline$V(+)$ & 9 & $\begin{array}{c}7 \\
(77.8)\end{array}$ & $\begin{array}{c}5 \\
(55.6)\end{array}$ \\
\hline$V( \pm)$ & 21 & $\begin{array}{c}14 \\
(66.7)\end{array}$ & $\begin{array}{c}12 \\
(57.1)\end{array}$ \\
\hline$V(-)$ & 9 & $\begin{array}{c}7 \\
(77.8)\end{array}$ & $\begin{array}{c}7 \\
(77.8)\end{array}$ \\
\hline
\end{tabular}

$$
\text { ( ) : \% }
$$

In the $\mathrm{S}(+)$ and $\mathrm{V}(+)$ groups the recovery of fullness is far greater than the disappearance of the upward push, whereas in the $S( \pm)$ and $V( \pm)$ groups the disappearance of the upward push and the recovery of fullness are well balanced. In the $\mathrm{S}(-)$ and $\mathrm{V}(-)$ groups the disappearance of the upward push of the mandibular anteriors is far greater than the recovery of fullness in the UL.

For the reasons given above, the frontal moire photographs of the facial soft tissue before and after improvement of anterior crossbites by means of an FKO apparatus did not show the subtle changes in the soft tissue as they did in the hard tissue. 
The surface area and volume of the UL are correlated with its width and depth and the upward push of the upper lip by the mandibular anteriors is considered to be a factor responsible for changes in the width and depth. As anterior bite improves the upward push disappears and the upper lip loses its support and recedes. The smaller the degree of upward push, the smaller the degree of recession of the upper lip when the upward push disappears. At the same time, in the presence of the deciduous or permanent cuspids on both sides of the maxilla, the upper lip, which has been deprived of the support of the mandibular anteriors, takes on a certain degree of fullness along its surface because of the cuspids that are present. On the contrary, in the absence of the deciduous or permanent cuspids, the recovery of fullness is not sufficient. In similar cases of bite improvement, using an FKO apparatus, a variety of changes occur in the UL depending upon the conditions of the anterior crossbite and the maxillary cuspids. Therefore, in some cases the profile of the patient does not improve after treatment.

\section{Conclusion}

Thirty-nine subjects suffering from anterior crossbite were treated using an FKO apparatus for improvement of bite. On the basis of their frontal moiré photographs and lateral cephalometric radiographs before and after treatment, studies were made on the changes in the facial soft tissue in each section and also on the relationships between the sections, especially those between the soft and hard tissues in the upper lip region. As a result, the author reached the following conclusions.

1. In the analytical values of the lateral cephalometric radiographs a correlation did not exist between the changes in the hard tissue and those in the surface area and volume of the soft tissue.

2. A significant correlation was noted between the rates of change in the surface area and volume in each rection.

3. A correlation existed in the rates of change between the surface area and volume and the width and depth of the upper lip region.

4. The changes in the surface area and volume of the upper lip region after an improvement of the bite suggest that they bear some relationship to the conditions of anterior crossbite and the presence of maxillary cuspids.

5. From the above findings, it was confirmed that by using moiré photographs taken before and after orthodontic treatment, it is possible to make an effective qualitative and quantitative analysis of the changes in the facial soft tissue brought about by orthodontic treatment. It is also possible to learn about the relationships between morphological changes in the soft tissue and changes in measurement values. The author, therefore, believes that moiré photography is an extremely simple and useful tool in making a disgnosis before orthodontic treatment and for studying the changes in the regions in and around the jaws.

\section{References}

[1] Suzuki, M., Kanaya, M. et al.: A measuring technique by moiré topography. Edited by Research Div., Optical Instrument Dept., Fuji Film Co., pp. 21, (1974). 
[2] Takamata, T. and Hashimoto, K.: An application to dentistry of a three-dimensional measuring technique by means of moiré contours. Matsumoto Univ. Sch. Dent., 2, 122-128, (1976).

[3] Shiorri, S.: A study on the symmetry of a normal human face by means of moiré photography. Oral Disease, 45, 147-169, (1978).

[4] Watanabe, K.: A study on facial symmetry-esp. on the median line. J. Nihon Univ. Sch. Dent., 53, 1037-1049, (1979).

[5] Kosuki, T., Kawano, Y. and Tashiro, H.: The evaluation of jaw restoration for a jaw tumor patient by moiré topography. Plastic Surg., 21, 620-632, (1978).

[6] Hashimoto, J.: Dynamic observations of the face by moiré contours - a change in masticatory movement. J. Dent., 73, 1818-1847, (1973).

[7] Miyazawa, T.: Sex determination from a morphological standpoint of the palatine arch and dental arch-an application of moiré topography and quantification. J. Nihon Univ. Sch. Dent., 52, 310-322, (1978).

[8] OKI, H.: A study on changes in the alveolar ridge-a change with the passage of time in its surface and volume after plastic surgery for the alveolar bone. J. Nihon Univ. Sch. Dent., 56, (1900).

[9] Kawai, M., Yамамото, T. et al.: A study on a three-dimensional measuring technique for facial morphology. J. J. Oral Surg., 20, 599-604, (1974).

[10] Матsumoto, M., Yамавe, Y. et al.: Facial morphology through moiré topcgraphy. J. Fukuoka Univ. Sch. Dent., 5, 139-147, (1978).

[11] MamonJi, Y.: A study on morphological changes in the facial soft tissue at the time of treatment for anterior crossbite by FKO apparatus-an application of moiré topography. Nihon Univ. Sch. Dent., 54, 762-776, (1980).

[12] Yamabe, Y., Urano, K. et al.: An orthodontic study by moiré topography. 1. on facial changes before and after improvement of bite for mandibular protraction. J. J. Orthodont., 39, 330342, (1980).

[13] Urano, K., Motoyama, K. et al.: An orthodontic study by moiré topography. 2. on facial changes before and after treatment for maxillary protraction. J. J. Orthodont., 40, 73-84, (1981).

[14] Suematsu, H.: A study on the profiles of mandibular protraction patients and changes brought about by orthodontic treatment. J. J. Orthodont., 27, 248-267, (1968).

[15] Yogosawa, F.: On relationships between the profile hard and soft tissues by means of cephalometric radiographs. J. J. Orthodont., 28, 33-60, (1969).

[16] Матsumoto, Y.: A study on the profile soft tissues of Japanese youths by means of cephalometric radiographs based on scientific measurement. J. Nihon Univ. Sch. Dent., 45, 706-714, (1971).

[17] ShiraI, T.: A comparative study of profile morphology of both hard and soft tissues on the periphery of the oral cavity. J. Dent., 62, 625-648, (1974).

[18] Burstone, C.J.: Integumental contour and extension patterns. Angle Orthodont., 29, 93104, (1959).

[19] Bloom, L.A.: Perioral profile changes in orthodontic treatment. Amer. J. Orthodont., 47, 371379, (1961).

[20] RudeE, D.A.: Proportional profile changes concurrent with orthodontic therapy. Amer. J. Orthodont., 50, 421-434, (1964).

[21] JACOBS, J.D.: Vertical lip changes from maxillary incisor retraction. Amer. J. Orthodont., 74, 396-404, (1978).

[22] Suzuki, K.: The faces of children suffering from Down's syndrome-an analysis by a facial photograph measuring technique. J. Pedodont., 16, 303-311, (1978).

[23] BJork, A.: The principle of the Andersen method of orthodontic treatment: A discussion based on cephalometric X-ray analysis of treated cases. Amer. J. Orthodont., 37, 437-548, (1951).

[24] Miura, F., Sakamoto, T., Irif, M. and Miura, S.: Results obtained from the treatment of mandibular protraction by means of FKO apparatus. J. Orthodont., 18, 40-45, (1959).

[25] Susami, R., Nakagawa, H. and Fuji, M.: A clinical study on the healing process of mandibular protraction, Vol. 2, morphological changes in the dental arch, jaws and facial bones 
brought about by the application of FKO technique. J. Orthodont., 23, 170-181, (1964).

[26] Fujita, T. and Terada, S.: Seitai Kansatsu (Observations of Living Bodies), the 12th Edition, published by Nanzando, Tokyo, 218-221, (1976).

[27] IIzuka, T. and Ishikawa, F.: On setting the measuring points in cephalometric radiography. J. Orthodont., 16, 66-75, (1957).

[28] Hirano, H., Suzuki, A., Kobayashi, K. and Okada, F.: On the position of the lips in relation to the teeth. A collection of studies by Dept. of Anatomy, Tokyo University of Dentistry. 7, 1-5, (1958).

[29] Yatake, Y.: A study on the faces of Japanese at old age based on scientific measurement. Dent. Med., 22, 2521-2538, (1959).

[30] Nakazawa, I.: Complete denture prosthodontics, the third issue, published by Nagasue Shoten, Tokyo, pp. 129, (1968).

[31] Kawabe, K.: Clinical Complete Denture Prosthodontics, the first issue, published by Nagase Shoten, Tokyo, p. 320, (1972). 